\title{
Sewage effluent as an alternative source for irrigation: Impact on soil properties and heavy metal status
}

\author{
Ahmed Saeed Abuzaid \\ Soils and Water Department, Faculty of Agriculture, Benha University, Egypt. \\ Corresponding author: ahmed.abuzaid@ fagr.bu.edu.eg
}

\begin{abstract}
Sewage irrigation may provide an alternative resource due to scarcity of fresh water in Egypt, thus such a practice should be evaluated. A number of 36 pairs of soil samples were collected; each pair consisted of one sample irrigated with fresh water and another irrigated with sewage water from two different sites in $\mathrm{Al}$ Qalyubia Governorate, Egypt. Sewage water-irrigated soils showed higher pH, EC, N, P, K, Fe Mn, Zn, Cd, Pb and Ni than fresh water-irrigated soils. Positive changes in soil properties occurred with sewage irrigation. Bulk density decreased field capacity, organic carbon and nutrients increased by sewage water irrigation. There was build-upin $\mathrm{Cd}, \mathrm{Pb}, \mathrm{Ni}$ and $\mathrm{Zn}$. Single pollution index (SPI) and pollution load index (PLI) indicated no pollution in fresh water irrigated soils as both parameters did not exceed 1.0. Sewage irrigated soils were moderately polluted. The contamination factor $(\mathrm{CF})$ revealed aconsidered contamination with $\mathrm{Pb}$ and high for $\mathrm{Cd}, \mathrm{Ni}$ and $\mathrm{Zn}$. The contamination degree was very high. Food crops cultivation in such soils should be practiced under precautions with a change in the cropping pattern.
\end{abstract}

Keyword: Sewage effluent, Soil properties, Heavy metals, Soil pollution

\section{Introduction}

Water shortage is one of the most serious issues in the Mediterranean region. The relatively uneven distribution of precipitation, high temperatures and increased demands for irrigation water are the main factors which contribute to this situation (Loutfy, 2011). Waste water irrigation is becoming a global phenomenon (Abaidoo et al., 2010)and is adapted increasingly in areas near to urban cities of developing countries (Sou/Dakouré et al., 2013). Sources of waste water are domestic sewage effluent (municipal wastewater), agricultural effluents, industrial effluents, and storm water (Kunhikrishnan et al., 2012).

Irrigation with sewage effluent have advantages such as providing economic and effective alternative sources of water (Ali et al., 2013) and saving fertilizer costs due to nutrients contents in water(Minhas et al., 2015). Different implications on soil properties were reported due to irrigation with sewage water (Lado and Ben-Hur, 2009). It adds large amounts of organic matter, macro and micronutrients (Yadav et al., 2002), increases salts (Mohammad Rusan et al., 2007) and decreases soil pH(Rattan et al., 2005).It may increase clay content and improve soil fertility (Masto et al., 2009).

Sewage water carries nutrients contains medium to high content of heavy metals (Butt et al., 2005). Thus, using it for irrigation could lead to accumulation of such metals in soil and foodstuff (Surdyk et al., 2010). Prolonged irrigation of sewage water could be a potential environmental risk(Mapanda et al., 2005). It releases organic contaminants into soil and water(Wang et al., 2015), leaches metals into underlying aquifers, affecting the quality of drinking water (Lottermoser, 2012) and cause health risks due to pathogenic infestation (Ahmad et al., 2011; Chopra and Pathak, 2012; Minhas et al., 2015).

Many farmers in developing countries irrigate crops using raw urban and industrial effluents. Therefore, soils, crops and groundwater would have to be assessed (Yadav et al., 2015). Some studies showed that heavy metals in long-term sewage irrigated soils may still be below the maximum permissible limit (Bao et al., 2014; Salakinkop and Hunshal, 2014). The present study aimed at assessing the effect of sewage water on soil properties and heavy metal contents in some areas in Qalubiya, Egypt.

\section{Materials and methods}

\subsection{The area of study}

The study was conducted during August to September 2014 at Tukh District, Al-Qalubiya Governorate, Egypt, located between latitude $30^{\circ} 18^{\prime}$ $28^{\prime \prime}$ to $30^{\circ} 23^{\prime} 28^{\prime \prime} \mathrm{N}$ and longitude $31^{\circ} 11^{\prime} 55^{\prime \prime}$ to $31^{\circ}$ $14^{\prime} 49^{\prime \prime}$ E, lying at 15 meters above sea level The climate of the area is characterized by hot rainless summer, short rainy mild winter, high evaporation and low relative humidity. Soil of the areais Typic Haplotorrerts.

\subsection{Collection of samples}

Soils irrigated with sewage effluents lies on the banks of the main drain of Al- Qalubiya Governorate (Fig. 1), while soils irrigated with fresh Nile receive their water from Al-Kawm Battin canal. Water samples were collected along with soil sample. At each site, a number of 36 soil samples $(0-30 \mathrm{~cm}$ layer) were collected separately from different site. 


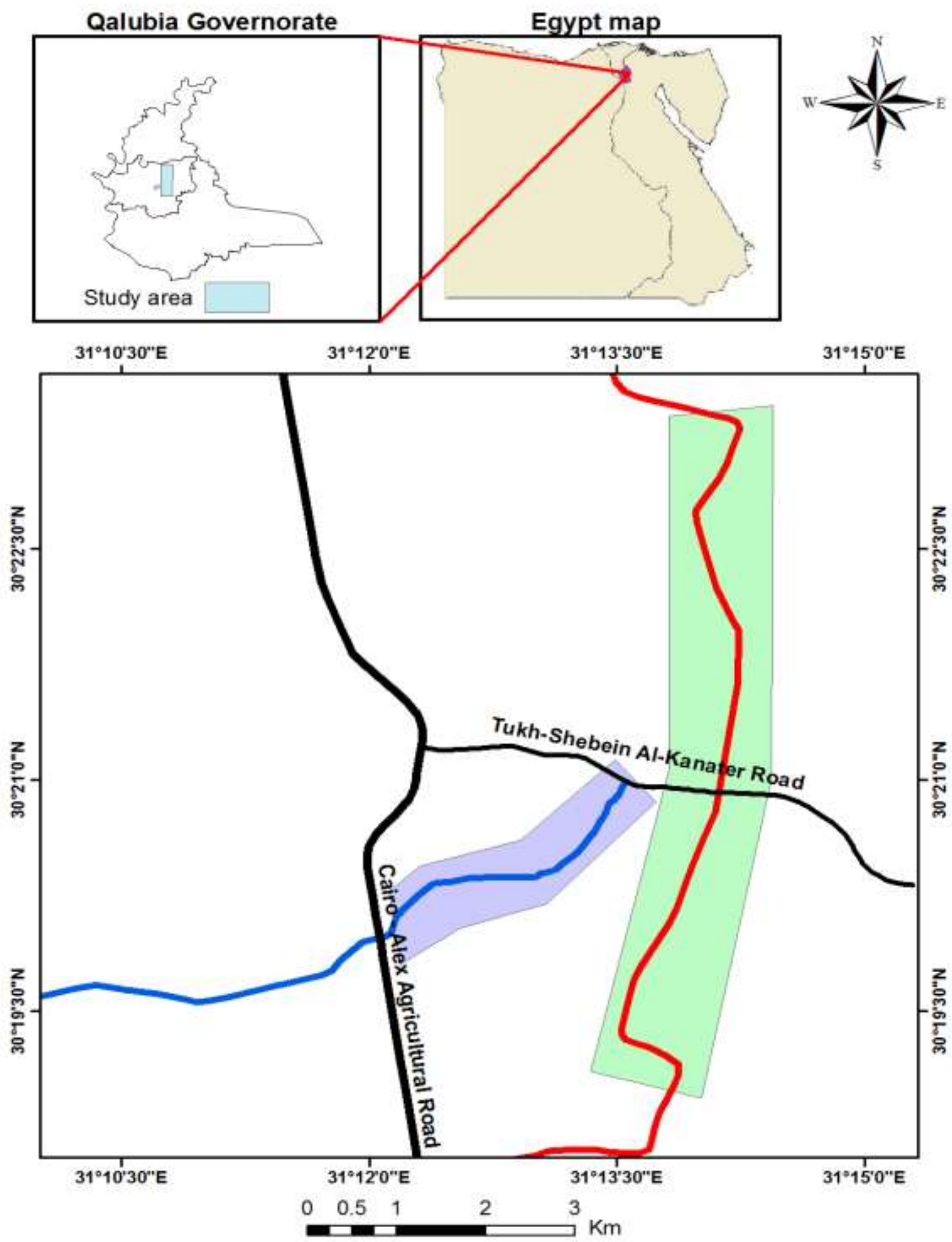

The main drain

Kawm Battin canal
Sewage irrigated soils

Fresh water irrigated soils

Fig. 1. Location map of the studied area 


\subsection{Analyses}

\subsubsection{Water analysis}

Analyses of samples were done according to methods cited by APHA (1999) and USDA (1954). The following parameters were calculated for water: Residual sodium carbonate $(\mathrm{RSC})=\left[\mathrm{CO}_{3}{ }^{2-}+\mathrm{HCO}_{3}^{-}\right]$ $-\left[\mathrm{Ca}^{2+}+\mathrm{Mg}^{2+}\right]$

Sodium Adsorption Ratio $(\mathrm{SAR})=\mathrm{Na}^{+}$

$$
/ \sqrt{\left[\mathrm{Ca}^{2+}+M g^{2+}\right]} / 2
$$

$\mathrm{Mg}$-ratio $=\mathrm{Mg}^{2+} /\left[\mathrm{Ca}^{2+}+\mathrm{Mg}^{2+}\right]$

Total Hardness $(\mathrm{TH})=\left[\mathrm{Ca}^{2+}+\mathrm{Mg}^{2+}\right] \times 50$, where, 50 is the equivalent weight of $\mathrm{CaCO}_{3}$

\subsubsection{Soil analysis}

Air-dried soil samples were crushed and passed through $2 \mathrm{~mm}$ sieve and analysed for chemical and physical properties according methods cited to Page et al. (1982), Klute (1986) and Soltanpour and Schwab (1977). Total contents of $\mathrm{Cd}, \mathrm{Pb}, \mathrm{Ni}$ and $\mathrm{Zn}$ were determined using aqua regia for digestion (ISO, 1995) and measured using HG-AAS Perkin Elmer 2380 .

\subsubsection{Assessment of heavy metal contamination}

Monitoring heavy metal in soilhelps to avoid health risk and further deterioration of the environment(AlMusharafi et al., 2013). Indices in the study were as follows:

\section{(1). Single pollution index (SPI)}

This index identifies metal toxicity induced by single element contamination (Saha et al., 2015). The equation is; $\mathrm{SPI}=\mathrm{Ci}$ / $\mathrm{Cp}$, where; $\mathrm{Ci}$ is metal content in soil; $\mathrm{Cp}$, the permissible concentration of the metals $\left(0.4,27,29\right.$ and $70 \mathrm{mg} \mathrm{kg}^{-1}$ for $\mathrm{Cd}, \mathrm{Pb}, \mathrm{Ni}$ and $\mathrm{Zn}$, respectively as mentioned by "Kabata-Pendias, 2010"). According to Chen et al.(2005) andLee et al.(2006)soil pollutionconcerningthe based on SPI are: low $(\leq 1)$, moderate $(1 \leq 3)$ or high $(>3)$.

\section{(2). Pollution load index (PLI)}

This index shows a simple comparative means for level of multi-element pollution(Bhuiyan et al., 2010). This parameter is calculated according to $\mathrm{Lu}$ et al.(2014)as follows:

$$
P L I=\sqrt[n]{S P I_{1} \times S P I_{2} \ldots \ldots \times S P I_{n}}
$$

Soil pollution occurs when PLI surpasses 1.0 (Tomlinson et al., 1980). The soils are considered background when PLI $=0$, while more values categorize soils in other six classes; i.e. $\leq 1$, unpolluted; $1: \leq 2$, unpolluted to moderately polluted; $2: \leq 3$, moderately polluted; $3: \leq 4$, moderately to highly polluted; $4: \leq 5$, highly polluted; or > 5, very highly polluted(Zhang et al., 2011).

\section{(3). Contamination Factor (CF)}

This parameter is used to identify soil contamination of the single heavy metal. It is calculated as follows: $\mathrm{CF}=\mathrm{Ci} / \mathrm{Co}$, where $\mathrm{Ci}$ is the metal content in soil, Cois the metal concent in the unpolluted (background) soil(Ferati et al., 2015). Soil contamination could be classified based on CF values as mentioned by Hakanson(1980)and Ghannem et al.(2016)into four classes: low $(<1)$, moderate (1- 3), considerable (3-6), or high $(>6)$

\section{(4). The contamination degree (CD)}

The total of contamination factors represents the degree of contamination (Saha et al., 2016). The calculated values of $\mathrm{CD}$ arrange soil in four contamination categories, low (below 8), moderate (8 $: \leq 16)$, considerable $(16: \leq 32)$ and very high $(\geq 32)$ (Hakanson, 1980; Krishna and Mohan, 2016)

\section{Results and discussion}

\subsection{Water quality for irrigation (Table 1)}

Water samples of the sewage effluent had a relatively high $\mathrm{pH}$ value compared with Nile water. Thus, they were within the safe limit for irrigation (Ayers and We stcot, 1994). This increase may be related to the relatively high content of both sodium and bicarbonate ions in sewage effluent (Chapman, 1996). Values of EC and total dissolved solids (TDS) were $0.37 \mathrm{dSm}^{-1}$ and $350 \mathrm{mgL}^{-1}$, respectively for fresh water, while the corresponding values for the sewage water were $1.10 \mathrm{dSm}^{-1}$ and $800 \mathrm{mgL}^{-1}$, respectively. The higher values of the sewage water maybe associated with discharge of brackish industrial effluents.

Basedon Ayers and Westcot (1994), there is no salinity hazardsfor the fresh water. Values of total suspended solids (TSS) were 50 and $110 \mathrm{mgL}^{-1}$ in the fresh and sewage water, respectively. Therefore, fresh water hadlow suspended solids, while sewage water had medium solids (Pescod, 1992). Values of total hardness $(\mathrm{TH})$ were 140 and $315 \mathrm{mgL}^{-1}$ for the fresh and the sewage water, respectively. The existence of soluble calcium and magnesium salts in waters is the main cause of water hardness (Chapman, 1996). According to Twort et al. (1994) the fresh water is slightly hard, while the sewage water is very hard. Values of SAR were 0.31 and 3.23 for the fresh and the sewage water, respectively. To assess potential infiltration problem, values of EC and SAR were used together (Ayers and Westcot, 1994). The fresh water had no restriction in use, while the sewage water had slight to moderate restrictions. According to USDA (1954), the fresh water is safe in use since it had no positive RSC. 
Table 1. Analyses of fresh and sewage water

\begin{tabular}{|c|c|c|c|c|}
\hline Parameters & Unit & Fresh water & Sewage water & $\begin{array}{c}\text { Standard level for } \\
\text { irrigation }\end{array}$ \\
\hline $\mathrm{pH}$ & $-\log \left[\mathrm{H}^{+}\right]$ & $7.23^{1}$ & $7.39^{1}$ & $6.5-8.4^{a}$ \\
\hline $\mathrm{EC}$ & $\mathrm{dSm}^{-1}$ & $0.37^{1}$ & $1.10^{2}$ & $<3^{a}$ \\
\hline TDS & $\mathrm{mgL}^{-1}$ & $350^{1}$ & $800^{2}$ & $<2000^{a}$ \\
\hline TSS & $\mathrm{mgL}^{-1}$ & $50^{w}$ & $110^{\mathrm{m}}$ & $<350^{\mathrm{b}}$ \\
\hline $\mathrm{Ca}$ & mmolc $\mathrm{L}^{-1}$ & 1.50 & 3.50 & $\mathrm{~nm}$ \\
\hline $\mathrm{Mg}$ & mmolc $\mathrm{L}^{-1}$ & 1.30 & 2.80 & $\mathrm{~nm}$ \\
\hline $\mathrm{Na}$ & mmolc $\mathrm{L}^{-1}$ & 0.37 & 5.71 & $\mathrm{~nm}$ \\
\hline $\mathrm{K}$ & mmolc $\mathrm{L}^{-1}$ & 0.22 & 0.84 & $\mathrm{~nm}$ \\
\hline $\mathrm{Cl}$ & mmolc $\mathrm{L}^{-1}$ & $1.10^{1}$ & $4.10^{2}$ & $<10^{\mathrm{a}}$ \\
\hline $\mathrm{CO}_{3}$ & mmolc $\mathrm{L}^{-1}$ & 0.00 & 0.00 & $\mathrm{~nm}$ \\
\hline $\mathrm{HCO}_{3}$ & mmolc $\mathrm{L}^{-1}$ & $2.20^{1}$ & $8.40^{2}$ & $<8.5^{\mathrm{a}}$ \\
\hline $\mathrm{SO}_{4}$ & mmolc $\mathrm{L}^{-1}$ & 0.15 & 0.35 & $\mathrm{~nm}$ \\
\hline SAR & mmolc $\mathrm{L}^{-1}$ & $0.31^{1}$ & $3.23^{2}$ & $<9^{a}$ \\
\hline RSC & mmolc $\mathrm{L}^{-1}$ & $-0.6^{*}$ & $2.10^{* *}$ & $<2.5^{\mathrm{c}}$ \\
\hline Mg-Ratio & mmolc $\mathrm{L}^{-1}$ & 46.43 & 44.44 & $<50^{\mathrm{d}}$ \\
\hline $\mathrm{TH}$ & $m g L^{-1}$ & $140^{\text {sh }}$ & $315^{\mathrm{vh}}$ & $<300^{\mathrm{e}}$ \\
\hline $\mathrm{NH}_{4}-\mathrm{N}$ & $\mathrm{mg} \mathrm{L}^{-1}$ & 4.10 & 11.20 & $\mathrm{~nm}$ \\
\hline $\mathrm{NO}_{3}-\mathrm{N}$ & $\mathrm{mg} \mathrm{L}^{-1}$ & $3.90^{1}$ & $19.40^{2}$ & $<30^{\mathrm{a}}$ \\
\hline $\mathrm{P}$ & $\mathrm{mg} \mathrm{L}^{-1}$ & 0.51 & 3.65 & $\mathrm{~nm}$ \\
\hline $\mathrm{Fe}$ & $\mathrm{mg} \mathrm{L}^{-1}$ & 0.03 & 4.44 & $5.00^{\mathrm{a}}$ \\
\hline Mn & $\mathrm{mg} \mathrm{L}^{-1}$ & 0.02 & 0.15 & $0.20^{\mathrm{a}}$ \\
\hline $\mathrm{Zn}$ & $\mathrm{mg} \mathrm{L}^{-1}$ & 0.01 & 3.56 & $2.00^{\mathrm{a}}$ \\
\hline $\mathrm{Cd}$ & $\mathrm{mg} \mathrm{L}^{-1}$ & n.d & 0.03 & $0.01^{\mathrm{a}}$ \\
\hline $\mathrm{Pb}$ & $\mathrm{mg} \mathrm{L}^{-1}$ & 0.01 & 6.11 & $5.00^{\mathrm{a}}$ \\
\hline Co & $\mathrm{mg} \mathrm{L}^{-1}$ & n.d & n.d & $0.05^{\mathrm{a}}$ \\
\hline $\mathrm{Ni}$ & $\mathrm{mg} \mathrm{L}^{-1}$ & 0.01 & 0.62 & $0.20^{\mathrm{a}}$ \\
\hline B & $\mathrm{mg} \mathrm{L}^{-1}$ & 0.01 & 0.02 & $<3^{a}$ \\
\hline
\end{tabular}

${ }^{\mathrm{a}}$ Ayers and Westcot (1994); ${ }^{\mathrm{b}}$ Pescod (1992); ${ }^{\mathrm{c}}$ USDA (1954); ${ }^{\mathrm{d}} \mathrm{FAO} / \mathrm{UNESCO}$ (1973); ${ }^{\mathrm{e}}$ Twort et al. (1994); $\mathrm{nm}=$ not mentioned in references; ${ }^{1}$ none restriction; ${ }^{2}$ slight to moderate restrictions; ${ }^{3}$ severe restrictions; probably save; ${ }^{* *}$ marginally suitable; ${ }^{\mathrm{w}}$ weak; ${ }^{\mathrm{m}}$ medium, ${ }^{\text {sh }}$ slightly hard; vh very hard.

The sewage water, with an RSC value of 2.10 mmolcL $^{-1}$ is marginally suitable $(1.25$ to 2.5 mmolcL $\left.{ }^{-1}\right)$.Excessive concentration of magnesium in irrigation water may cause deterioration in soil structure due to increasing ESP (Rahman and Rowell, 1979). Potential harmful effect occurs when $\mathrm{Mg}$ ratio surpasses $50 \%$ i.e. when $\mathrm{Mg}^{2+}$ exceeds $\mathrm{Ca}^{2+}$ (FAO-UNESCO, 1973). Accordingly, no $\mathrm{Mg}$ harmful effect is expected for irrigation as $\mathrm{Mg}$ is $<50$ $\%$ for both waters. Values of Clwere1.10 and 4.10 mmolcL ${ }^{-1}$ for the fresh and sewage water, respectively. Values of B were 0.01 and $0.02 \mathrm{mgL}^{-1}$, for same waters. Both SAR and chloride imposed slight to moderate restrictions in using sewage water, while no restriction concerning B (Ayers and Westcott, 1994).Content of metals did not surpass the maximum acceptable concentration suggested by Ayers and Westcot (1994), except Zn (3.56), Cd (0.03), $\mathrm{Pb}(6.11)$ and $\mathrm{Ni}(0.62)$ in sewage water that exceeded the permissible levels of 2.0, 0.01, 5.0 and $0.20 \mathrm{mgL}^{-1}$, respectively. Contents of $\mathrm{NH}_{4}-\mathrm{N}$ and $\mathrm{NO}_{3}-\mathrm{N}$ were 4.10 and $3.90 \mathrm{mgL}^{-1}$, respectively for fresh water and 11.20 and $19.40 \mathrm{mgL}^{-1}$, respectively for sewage water. No restriction in using the fresh water, while a slight to moderate restriction is imposed when using sewage water (Ayers and Westcot, 1994). P content was 0.51 and $6.65 \mathrm{mgL}^{-1}$ in fresh and sewage water, respectively.

\subsection{Effect of water quality on soil properties}

Results in Table 2 show that soil $\mathrm{pH}$ varied from 7.39 to 7.81 in the fresh water-irrigated soils and from 7.45 to 7.99 in the sewage water irrigated soils. The $\mathrm{pH}$ of soils irrigated with fresh water was lower than those irrigated with sewage water.

There was $56.72 \%$ increase in EC in soils irrigated with sewage water compared with those irrigated with fresh water. EC values for the fresh water-irrigated soils ranged from 0.64 to $1.75 \mathrm{dSm}^{-1}$ with an average of $0.87 \mathrm{dSm}^{-1}$, while the corresponding values for sewage-irrigated soils ranged from 0.56 to $5.77 \mathrm{dSm}^{-1}$ with an average of $2.01 \mathrm{dSm}^{-1}$. These results agree with those of Gwenzi and Munondo (2008) and Ghosh et al.(2012) who recorded increased values of $\mathrm{pH}$ and $\mathrm{EC}$ in soils irrigated with wastewater. 
Table 2. Properties of the studied soils

\begin{tabular}{cccccccccc}
\hline \multirow{2}{*}{ Parameter } & \multirow{2}{*}{ Unit } & \multicolumn{3}{c}{ Fresh water-irrigated soil } & \multicolumn{3}{c}{ Sewage water-irrigated soils } \\
\cline { 3 - 9 } & & Min. & Max. & Mean & S.D & Min. & Max. & Mean & S.D \\
\hline WHC & \% & 34.70 & 36.67 & 35.55 & 0.50 & 33.33 & 38.00 & 36.07 & 1.50 \\
$\mathrm{Bd}$ & $\mathrm{Mgm}^{-3}$ & 1.18 & 1.34 & 1.25 & 0.05 & 1.11 & 1.28 & 1.20 & 0.06 \\
$\mathrm{O} . \mathrm{C}$ & $\mathrm{gkg}^{-1}$ & 7.65 & 12.75 & 10.77 & 1.51 & 8.55 & 15.60 & 11.98 & 1.98 \\
$\mathrm{pH}$ & $\left.-\operatorname{log~[H}^{+}\right]$ & 7.39 & 7.81 & 7.57 & 0.13 & 7.45 & 7.99 & 7.62 & 0.21 \\
$\mathrm{ECe}$ & $\mathrm{dS} \mathrm{m}^{-1}$ & 0.64 & 1.75 & 0.87 & 0.35 & 0.56 & 5.77 & 2.01 & 1.69 \\
$\mathrm{Ca}^{2+}$ & $\mathrm{mmolc} \mathrm{L}^{-1}$ & 2.60 & 7.60 & 3.88 & 1.47 & 3.70 & 23.00 & 8.72 & 8.09 \\
$\mathrm{Mg}^{2+}$ & $\mathrm{mmolc} \mathrm{L}^{-1}$ & 2.80 & 4.10 & 3.42 & 0.41 & 2.40 & 26.40 & 8.00 & 7.90 \\
$\mathrm{Na}^{+}$ & $\mathrm{mmolc} \mathrm{L}^{-1}$ & 0.64 & 1.45 & 0.92 & 0.26 & 0.66 & 9.25 & 2.21 & 2.67 \\
$\mathrm{~K}^{+}$ & $\mathrm{mmolc} \mathrm{L}^{-1}$ & 0.20 & 1.24 & 0.65 & 0.33 & 0.23 & 0.91 & 0.49 & 0.22 \\
$\mathrm{Cl}^{-}$ & $\mathrm{mmolc} \mathrm{L}^{-1}$ & 2.40 & 5.70 & 3.36 & 0.97 & 2.00 & 52.80 & 11.00 & 15.81 \\
$\mathrm{CO}_{3}=$ & $\mathrm{mmolc} \mathrm{L}^{-1}$ & 0.00 & 0.00 & 0.00 & 0.00 & 0.00 & 0.00 & 0.00 & 0.00 \\
$\mathrm{HCO}_{3}^{-}$ & $\mathrm{mmolc} \mathrm{L}^{-1}$ & 2.80 & 4.40 & 3.62 & 0.56 & 2.60 & 4.00 & 3.29 & 0.50 \\
$\mathrm{SO}_{4}=$ & $\mathrm{mmolc} \mathrm{L}^{-1}$ & 0.40 & 5.49 & 1.89 & 1.53 & 0.51 & 27.83 & 5.14 & 8.58 \\
SAR & $\mathrm{mmolc} \mathrm{L}^{-1}$ & 0.36 & 0.64 & 0.48 & 0.11 & 0.37 & 1.87 & 0.72 & 0.46 \\
Total N & $\mathrm{g} \mathrm{kg}^{-1}$ & 2.80 & 5.95 & 3.62 & 1.11 & 2.45 & 52.50 & 18.08 & 15.83 \\
$\mathrm{AB}-\mathrm{DTPA}-\mathrm{P}$ & $\mathrm{mg} \mathrm{kg}^{-1}$ & 1.42 & 9.94 & 4.26 & 2.78 & 3.25 & 13.19 & 7.85 & 3.80 \\
$\mathrm{AB}-\mathrm{DTPA}-\mathrm{K}$ & $\mathrm{mg} \mathrm{kg}^{-1}$ & 197.43 & 679.82 & 474.68 & 74.33 & 298.01 & 722.67 & 502.62 & 39.69 \\
$\mathrm{AB}-\mathrm{DTPA}-\mathrm{Fe}$ & $\mathrm{mg} \mathrm{kg}^{-1}$ & 2.14 & 8.32 & 4.15 & 2.21 & 3.80 & 43.14 & 10.09 & 12.47 \\
$\mathrm{AB}-\mathrm{DTPA}-\mathrm{Mn}$ & $\mathrm{mg} \mathrm{kg}^{-1}$ & 8.22 & 20.94 & 13.50 & 4.64 & 6.16 & 76.68 & 22.04 & 21.82 \\
\hline
\end{tabular}

On the other hand, Yao et al.(2013) mentioned that wastewater irrigation has not had any significant effect on $\mathrm{pH}$ or EC.Soil organic carbon ranged from 7.65 to 12.75 in the fresh water-irrigated soils and from 8.55 to $15.60 \mathrm{gkg}^{-1}$ in the sewage waterirrigated soils. Average of soils irrigated with fresh water was $10.77 \mathrm{gkg}^{-1}$ and for the sewage-irrigated soils it was $11.98 \mathrm{gkg}^{-1}$. Thus, the sewage-irrigated soils had $10.10 \%$ more organic carbon than the fresh water-irrigated soils. These results agree with Yao et al.(2013)Yang et al.(2015) who found an increase in soil organic carbon in sites irrigated with sewage water compared to those receive fresh water. Moreover Al-Omran et al.(2012) reported significantincrease in soil organic carbon in sewageirrigated soils as compared to well water-irrigated ones. Values of the water holding capacity ranged between 34.70 and $36.67 \%$ with an average of $35.55 \%$ in soils irrigated with fresh water and between 33.33 and $38.00 \%$ with an average of $36.07 \%$ in soils irrigated with sewage water. These results indicatea slight increase of $1.5 \%$ in soil water holding capacity. Values of soil bulk density varied from1.18 to $1.34 \mathrm{Mgm}^{-3}$ with an average of 1.25 $\mathrm{Mgm}^{-3}$ in fresh water-irrigated soils; while the corresponding values of sewage water-irrigated soils were 1.11 and $1.28 \mathrm{Mgm}^{-3}$ with an average of 1.20 $\mathrm{Mgm}^{-3}$. Thus, sewage water had bulk density lower by $4.0 \%$ than fresh water-irrigated soils. These results agree with Mathan(1994) who stated that sewage irrigation decreased soil bulk density. Contents of $\mathrm{N}, \mathrm{P}, \mathrm{K}, \mathrm{Fe}$ and $\mathrm{Mn}$ in sewage-irrigated soils increased by $5, \quad 1.8, \quad 5.9, \quad 2.4$ and 1.6timesabovethose which received fresh water.
Total $\mathrm{N}$ rangedfrom 2.80 to $5.95 \mathrm{gkg}^{-1}$ (average of $\left.3.62 \mathrm{gkg}^{-1}\right)$ in fresh water-irrigated soils and from 2.45 to $52.50 \mathrm{gkg}^{-1}$ (average of $18.08 \mathrm{gkg}^{-1}$ )insewage water-irrigated soils. $\mathrm{P}$ in fresh water irrigated soils ranged from 1.42 to $9.94 \mathrm{mgkg}^{-1}$ (average of $4.26 \mathrm{mgkg}^{-1}$ ), while those of soils which received sewage water ranged between 3.25 and $13.19 \mathrm{mgkg}^{-1}$ (average of $7.75 \mathrm{mgkg}^{-1}$ ). Available $\mathrm{K}$ in fresh water irrigated soils ranged from 197.43 to $679.82 \mathrm{mgkg}^{-}$ ${ }^{1}$ with (average of $474.68 \mathrm{mgkg}^{-1}$ ) and from 289.01 to $722.67 \mathrm{mgkg}^{-1}$ in sewage irrigated soils (average of $502.62 \mathrm{mgkg}^{-1}$ ). Available Fe ranged from 2.14 to $8.32 \mathrm{mgkg}^{-1}$ in fresh water-irrigated soils and from 3.80 to $43.14 \mathrm{mgkg}^{-1}$ in sewage water-irrigated soils. Available Mn ranged from 8.22 to $20.94 \mathrm{mgkg}^{-1}$ in fresh water irrigated soils; and 6.16 to $76.68 \mathrm{mgkg}^{-1}$ in sewage water-irrigated soils. These results are in agreement withthose reported by Angin et al.(2005) and $\mathrm{Xu}$ et al.(2010)who found a considerable increase in nutrient load in soils irrigated with effluent over those received fresh water

\subsection{Heavy metal contents in soils}

The total content of heavy metals (Table 3)indicatesa build-up of $\mathrm{Cd}, \mathrm{Pb}, \mathrm{Ni}$ and $\mathrm{Zn}$ in the sewage waterirrigated soils. Contents of $\mathrm{Cd}, \mathrm{Pb}, \mathrm{Ni}$ and $\mathrm{Zn}$ were greater by $14.3,2.9,35.3$ and 9.1 folds, respectively in the sewage-irrigated soils over the fresh waterirrigated soils. This agrees with Bao et al.(2014) and Meng et al.(2016) who noteda considerable accumulation of heavy metals in soils after long-term sewage water irrigation. Chung et al.(2011) reported a slight increase of heavy metal contents in soils after long-term irrigation with sewage water.

Table 3. Total heavy metal contents $\left(\mathrm{mg} \mathrm{kg}^{-1}\right)$ in the studied soils 


\begin{tabular}{ccccccccc}
\hline \multirow{2}{*}{ Metal } & \multicolumn{3}{c}{ Fresh water-irrigated soils } & \multicolumn{4}{c}{ Sewage water-irrigated soils } \\
\cline { 2 - 9 } & Min. & Max. & Mean & S.D & Min. & Max. & Mean & S.D \\
\hline $\mathrm{Cd}$ & 0.05 & 0.09 & 0.07 & 0.01 & 0.89 & 1.12 & 1.03 & 0.08 \\
$\mathrm{~Pb}$ & 3.17 & 13.17 & 9.42 & 4.38 & 4.38 & 58.75 & 26.88 & 9.4 \\
$\mathrm{Ni}$ & 0.64 & 3.63 & 1.91 & 1.11 & 34.3 & 86.24 & 67.06 & 7.9 \\
$\mathrm{Zn}$ & 3.96 & 17.08 & 11.64 & 4.05 & 80.39 & 129.41 & 106.32 & 9.8 \\
\hline
\end{tabular}

\subsection{Heavy metals status}

As shown in Fig. 2, no metal pollution occurred in the fresh water-irrigated soils since the mean values of SPI and PLI did not exceed 1.0. On the other hand, values of SPI for the sewage-irrigated soils were 2.5, 1.0, 2.3 and 1.5 for $\mathrm{Cd}, \mathrm{Pb}, \mathrm{Ni}$ and $\mathrm{Zn}$ respectively. Soil pollution with heavy metals was low for $\mathrm{Pb}$ and moderate for $\mathrm{Cd}, \mathrm{Ni}$ and $\mathrm{Zn}$. Regarding the overall pollution, the PLI was1.6 and hence, the soils maybe considered unpolluted to moderately polluted. These results agree with those of Liu et al.(2005), Sun et al.(2013), Hu et al.(2014)who reported that sewage irrigation caused pollution of soils with heavy metals. The mean values of $\mathrm{CF}$ as shown in Fig.3 were 15.3, 3.3, 51.7 and 11.3 for $\mathrm{Cd}, \mathrm{Pb}, \mathrm{Ni}$ and $\mathrm{Zn}$, respectively. These results indicate contamination caused by anthropogenic activitiesas mentioned by Moore et al.(2011)since CF values exceeded 1.0. Thus, the soils could be classed into two contamination classes; considerable for $\mathrm{Pb}$ and high for $\mathrm{Cd}, \mathrm{Ni}$ and $\mathrm{Zn}$. Regarding the contamination degree, the soils are of high degree of contamination since CD exceeded 32. These results agree with Liu et al.(2005)and Balkhair and Ashraf (2016)who reported hazards of heavy metal contamination in agricultural fields due to irrigation with sewage water.

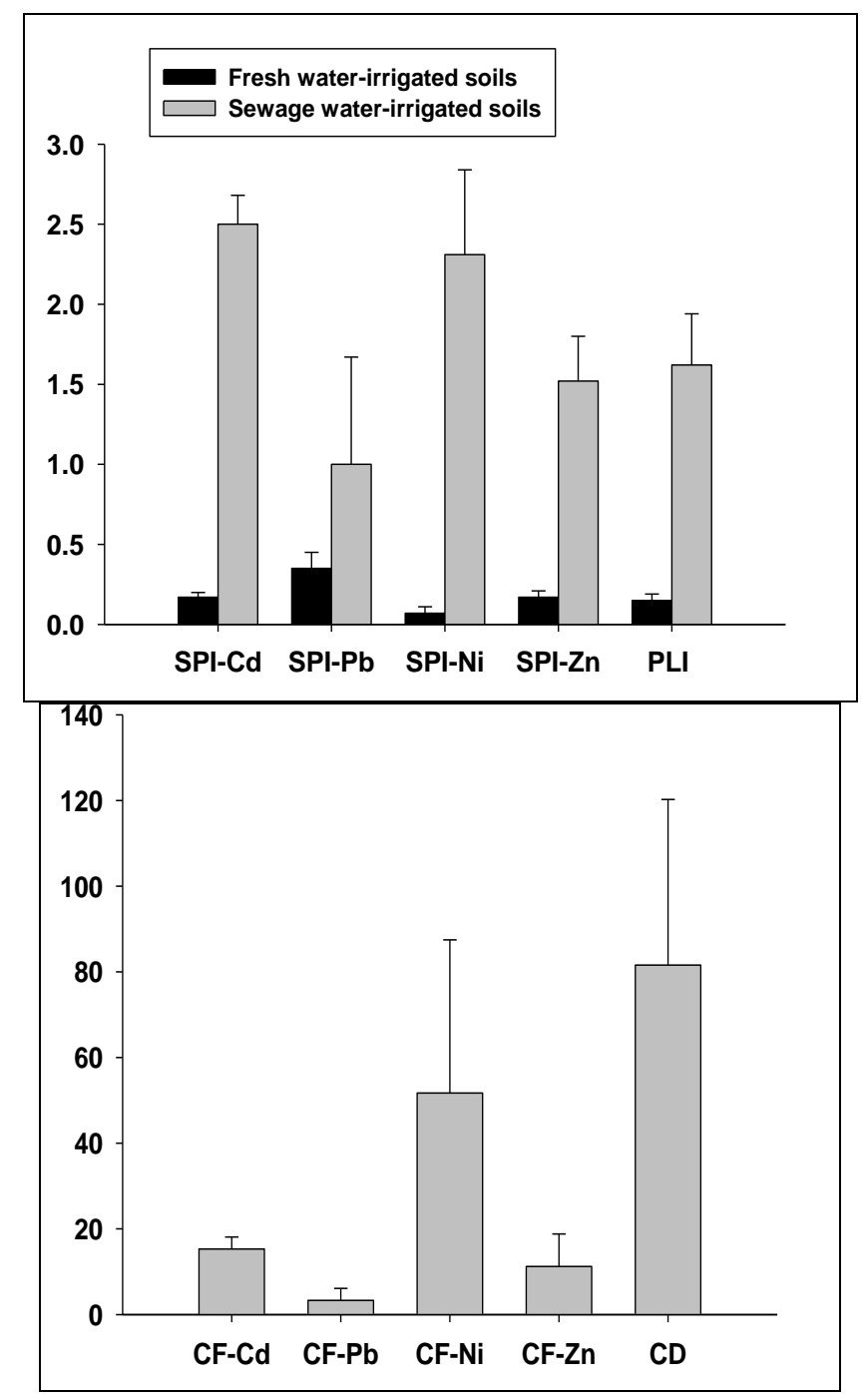

Fig. 2. Pollution indices for the studied soilsFig. 3. Contamination indices for the sewage Water-irrigated soils 


\section{Conclusion}

Water shortage has been a serious issue which preoccupies the public opinion in Egypt. Accordingly, the use of unconventional resources should be considered for agriculture proposes. Sewage effluent may providea source of irrigation but its use must be well evaluated. A comparison between soils irrigated with sewage effluent and those which receive Nile fresh water was done. Sewage irrigation resulted in some positive effects such as providing organic matter and nutrientsto soil. On the other hand, there was a build-up in EC, $\mathrm{pH}$ and heavy metals in sewage-irrigated soils. Single pollution index (SPI) and pollution load index (PLI) indicate a moderate pollution in sewage irrigated soils. The contamination factor (CF) indicates contamination with $\mathrm{Pb}, \mathrm{Cd}, \mathrm{Ni}$ and $\mathrm{Zn}$. Therefore, one or more scenario for remediation should be performed. An alternative possible solution for such problem could be achieved by changing land usepattern from food crops cultivation to others such as fibers.

\section{Acknowledgement}

The author expresses his deep thanks to Prof. Dr. Ali Ahmed Abd El-Salam and Prof. Dr. Hassan Hamza Abbas, Soils and Water Department, Faculty of Agriculture, Moshtohor, Benha University for their help and encouragement during the study.

\section{References}

Abaidoo, R., Keraita, B., Drechsel, P., Dissanayake, P., Maxwell, A., 2010. Soil and Crop Contamination Through Wastewater Irrigation and Options for Risk Reduction in Developing Countries. In: Dion, P. (Ed.), Soil Biology and Agriculture in the Tropics. Springer Berlin Heidelberg, pp. 275-297.

Ahmad, K., Ibrahim, M., Khan, Z.I., Rizwan, Y., Ejaz, A., Fardsous, A., Gondal, S., Lee, D.J., Al-Yemeni, M., 2011. Effect of sewage water on mineral nutritive potential of six fodder species grown under semiarid conditions. Saudi Journal of Biological Sciences 18, 317-321.

Al-Omron, A.M., El-Maghraby, S.E., Nadeem, M.E.A., El-Eter, A.M., Al-Mohani, H., 2012. Long term effect of irrigation with the treated sewage effluent on some soil properties of AlHassa Governorate, Saudi Arabia. Journal of the Saudi Society of Agricultural Sciences 11, 15-18.

Ali, H.M., Siddiqui, M.H., Khamis, M.H., Hassan, F.A., Salem, M.Z.M., El-Mahrouk, E.-S.M., 2013. Performance of forest tree Khaya senegalensis (Desr.) A. Juss. under sewage effluent irrigation. Ecological Engineering 61, Part A, 117-126.
Al-Musharafi, S., Mahmoud, I., Al-Bahry, S., 2013. Heavy metal pollution from treated sewage effluent. APCBEE Procedia 5, 344-348.

American Public Health association (APHA), 1999. Standard methods for the examination of water and wastewater. $20^{\text {th }}$ ed. American Public Health Association, American Water Works Association, Water Environment Federation, Washington, D.C., USA.

Angin, I., Yaganoglu, A.V., Turan, M., 2005. Effects of Long-Term Wastewater Irrigation on Soil Properties. Journal of Sustainable Agriculture 26, 31-42.

Ayers R.S, Westcot, D.W. 1994. Water quality for agriculture: FAO Irrigation and Drainage Paper 29. Revision. 1. pp. 1-130.

Balkhair, K.S., Ashraf, M.A., 2016. Field accumulation risks of heavy metals in soil and vegetable crop irrigated with sewage water in western region of Saudi Arabia. Saudi Journal of Biological Sciences 23, S32-S44.

Bao, Z., Wu, W., Liu, H., Chen, H., Yin, S., 2014. Impact of Long-Term Irrigation with Sewage on Heavy Metals in Soils, Crops, and Groundwater-a Case Study in Beijing. Pol. J Environ. Stud 23, 309-318.

Bhuiyan, M.A., Parvez, L., Islam, M., Dampare, S.B., Suzuki, S., 2010. Heavy metal pollution of coal mine-affected agricultural soils in the northern part of Bangladesh. Journal of Hazardous Materials 173, 384-392.

Butt, M.S., Sharif, K., Bajwa, B.E., Aziz, A., 2005. Hazardous effects of sewage water on the environment. Management of Environmental Quality: An International Journal 16, 338-346.

Chapman, D.V. (ed. 1996). Water Quality Assessments: A guide to use Biota, Sediments and Water" Environmental Monitoring. Second Edition. UNESCO, WHO, and UNEP. E \& FN Spon, London UK.

Chen, T.-B., Zheng, Y.-M., Lei, M., Huang, Z.-C., Wu, H.-T., Chen, H., Fan, K.-K., Yu, K., Wu, X., Tian, Q.-Z., 2005. Assessment of heavy metal pollution in surface soils of urban parks in Beijing, China. Chemosphere 60, 542-551.

Chopra, A., Pathak, C., 2012. Bioaccumulation and translocation efficiency of heavy metals in vegetables grown on long-term wastewater irrigated soil near Bindal River, Dehradun. Agricultural Research 1, 157-164.

Chung, B., Song, C., Park, B., Cho, J., 2011. Heavy metals in brown rice (Oryza sativa L.) and soil after long-term irrigation of wastewater discharged from domestic sewage treatment plants. Pedosphere 21, 621-627.

FAO/UNESCO, 1973. Irrigation, drainage and salinity. An international sourcebook. Paris, UNESCO/ Hutchinson \& CO (Publishers), London. 510p. 
Ferati, F., Kerolli-Mustafa, M., Kraja-Ylli, A., 2015. Assessment of heavy metal contamination in water and sediments of Trepça and Sitnica rivers, Kosovo, using pollution indicators and multivariate cluster analysis. Environmental Monitoring and Assessment 187, 1-15.

Ghannem, S., Khazri, A., Sellami, B., Boumaiza, M., 2016. Assessment of heavy metal contamination in soil and Chlaenius (Chlaeniellus) olivieri (Coleoptera, Carabidae) in the vicinity of a textile factory near Ras Jbel (Bizerte, Tunisia). Environmental Earth Sciences 75, 1-10.

Ghosh, A.K., Bhatt, M.A., Agrawal, H.P., 2012. Effect of long-term application of treated sewage water on heavy metal accumulation in vegetables grown in Northern India. Environmental Monitoring and Assessment 184, 1025-1036.

Gwenzi, W., Munondo, R., 2008. Long-term impacts of pasture irrigation with treated sewage effluent on nutrient status of a sandy soil in Zimbabwe. Nutr Cycl Agroecosyst 82, 197-207.

Hakanson, L., 1980. An ecological risk index for aquatic pollution control. A sedimentological approach. Water Research 14, 975-1001.

Hu, M.H., Yuan, J.H., Lai, C.T., 2014. Pollution loss rate assessment of soil heavy metals in paddy field with sewage irrigation in Guixi city, Jiangxi Province, China. In: Wang, L. (Ed.), International Conference Machinery, Electronics and Control Simulation, pp. 658663.

International Standard Organization (ISO), 11466, 1995. Soil quality-Extraction of trace elements soluble in aqua regia.

Kabata-Pendias, A., 2010. Trace elements in soils and plants. CRC press.

Klute, A., 1986. Methods of soil analysis, part 1. Physical and mineralogical methods, second ed. Amer. Soc. of Agron., Madison, Wisconsin, USA.

Krishna, A.K., Mohan, K.R., 2016. Distribution, correlation, ecological and health risk assessment of heavy metal contamination in surface soils around an industrial area, Hyderabad, India. Environmental Earth Sciences 75, 1-17.

Kunhikrishnan, A., Bolan, N.S., Müller, K., Laurenson, S., Naidu, R., Kim, W.-I., 2012. Chapter Five - The Influence of Wastewater Irrigation on the Transformation and Bioavailability of Heavy Metal(Loid)s in Soil. In: Donald, L.S. (Ed.), Advances in Agronomy. Academic Press, pp. 215-297.

Lado, M., Ben-Hur, M., 2009. Treated domestic sewage irrigation effects on soil hydraulic properties in arid and semiarid zones: A review. Soil and Tillage Research 106, 152-163.
Lee, C.S.-1., Li, X., Shi, W., Cheung, S.C.-n., Thornton, I., 2006. Metal contamination in urban, suburban, and country park soils of Hong Kong: a study based on GIS and multivariate statistics. Science of the Total Environment 356, 45-61.

Liu, W.H., Zhao, J.Z., Ouyang, Z.Y., Soderlund, L., Liu, G.H., 2005. Impacts of sewage irrigation on heavy metal distribution and contamination in Beijing, China. Environment International 31, 805-812.

Lottermoser, B., 2012. Effect of long-term irrigation with sewage effluent on the metal content of soils, Berlin, Germany. Environ Geochem Health 34, 67-76.

Loutfy, N., 2011. Reuse of Wastewater in Mediterranean Region, Egyptian Experience. In: Barceló, D., Petrovic, M. (Eds.), Waste Water Treatment and Reuse in the Mediterranean Region. Springer Berlin Heidelberg, pp. 183-213.

Lu, X., Zhang, X., Li, L.Y., Chen, H., 2014. Assessment of metals pollution and health risk in dust from nursery schools in Xi'an, China. Environmental research 128, 27-34.

Mapanda, F., Mangwayana, E.N., Nyamangara, J., Giller, K.E., 2005. The effect of long-term irrigation using wastewater on heavy metal contents of soils under vegetables in Harare, Zimbabwe. Agriculture, Ecosystems \& Environment 107, 151-165.

Masto, R., Chhonkar, P., Singh, D., Patra, A., 2009. Changes in soil quality indicators under longterm sewage irrigation in a sub-tropical environment. Environ Geol 56, 1237-1243.

Mathan, K.K., 1994. Studies on the influence of long-term municipal sewage-effluent irrigation on soil physical properties. Bioresource Technology 48, 275-276.

Meng, W., Wang, Z., Hu, B., Wang, Z., Li, H., Goodman, R.C., 2016. Heavy metals in soil and plants after long-term sewage irrigation at Tianjin China: A case study assessment. Agric. Water Manage. 171, 153-161.

Minhas, P.S., Khajanchi, L., Yadav, R.K., Dubey, S.K., Chaturvedi, R.K., 2015. Long term impact of waste water irrigation and nutrient rates: I. Performance, sustainability and produce quality of peri urban cropping systems. Agricultural Water Management 156, 100-109.

Mohammad Rusan, M.J., Hinnawi, S., Rousan, L., 2007. Long term effect of wastewater irrigation of forage crops on soil and plant quality parameters. Desalination 215, 143-152.

Moore, F., Esmaeili, K., Keshavarzi, B., 2011. Assessment of Heavy Metals Contamination in Stream Water and Sediments Affected by the Sungun Porphyry Copper Deposit, East Azerbaijan Province, Northwest Iran. Water Quality, Exposure and Health 3, 37-49. 
Page, A.L., Miller, R.H., Keeny, D.R., 1982. Methods of soil analysis, part 2. Chemical and microbial properties. second ed. Amer. Soc. of Agron., Madison, Wisconsin, USA.

Pescod, M.B., 1992. Wastewater treatment and use in agriculture. FAO irrigation and drainage paper 47.

Rahman, W.A., Rowell, D.L., 1979. The influence of magnesium in saline and sodic soils: a specific effect or a problem of cation exchange? Journal of Soil Science 30, 535-546.

Rattan, R., Datta, S., Chhonkar, P., Suribabu, K., Singh, A., 2005. Long-term impact of irrigation with sewage effluents on heavy metal content in soils, crops and groundwater - a case study. Agriculture, Ecosystems \& Environment 109, 310-322.

Saha, N., Rahman, M.S., Jolly, Y.N., Rahman, A., Sattar, M.A., Hai, M.A., 2016. Spatial distribution and contamination assessment of six heavy metals in soils and their transfer into mature tobacco plants in Kushtia District, Bangladesh. Environ Sci Pollut Res 23, 34143426.

Saha, S., Hazra, G., Saha, B., Mandal, B., 2015. Assessment of heavy metals contamination in different crops grown in long-term sewageirrigated areas of Kolkata, West Bengal, India. Environmental Monitoring and Assessment 187, 1-12.

Salakinkop, S.R., Hunshal, C.S., 2014. Domestic sewage irrigation on dynamics of nutrients and heavy metals in soil and wheat (Triticum aestivum L.) production. Int J Recycl Org Waste Agricult 3, 1-11.

Soltanpour, P.N., Schwab, A.P., 1977. A new soil test for simultaneous extraction of macro- and micro-nutrients in alkaline soils. Communications in Soil Science and Plant Analysis 8, 195-207.

Sou/Dakouré, M.Y., Mermoud, A., Yacouba, H., Boivin, P., 2013. Impacts of irrigation with industrial treated wastewater on soil properties. Geoderma 200-201, 31-39.

Sun, W.H., Jiang, Y.X., Li, X., 2013. Research of the Evaluation on Heavy-metal Pollution in Rice by Sewage Irrigation. In: Tang, X., Zhong, W., Zhuang, D., Li, C., Liu, Y. (Eds.), Progress in Environmental Protection and Processing of Resource, Pts 1-4, pp. 1594-1599.

Surdyk, N., Cary, L., Blagojevic, S., Jovanovic, Z., Stikic, R., Vucelic-Radovic, B., Zarkovic, B., Sandei, L., Pettenati, M., Kloppmann, W.,
2010. Impact of irrigation with treated low quality water on the heavy metal contents of a soil-crop system in Serbia. Agricultural Water Management 98, 451-457.

Tomlinson, D., Wilson, J., Harris, C., Jeffrey, D., 1980. Problems in the assessment of heavymetal levels in estuaries and the formation of a pollution index. Helgoländer Meeresuntersuchungen 33, 566-575.

Twort, A.C., Law, F.M., Growely, F.W., Ratanayaka, D.D. (1994). Water supply, $4^{\text {th }}$ edition. John Wiley and Sons., Inc., 605 third A venue, New York, 10158.

USDA. 1954. Diagnosis and improvement of saline and alkali soils. U.S. Agric. Handbook, No. 60, U.S. Dept. Agric،. Washington D.C.,160 p.

Wang, S., Wu, W., Liu, F., Yin, S., Bao, Z., Liu, H., 2015. Spatial distribution and migration of nonylphenol in groundwater following longterm wastewater irrigation. Journal of Contaminant Hydrology 177-178, 85-92.

Xu, J., Wu, L., Chang, A.C., Zhang, Y., 2010. Impact of long-term reclaimed wastewater irrigation on agricultural soils: A preliminary assessment. Journal of Hazardous Materials 183, 780-786.

Yadav, R.K., Goyal, B., Sharma, R.K., Dubey, S.K., Minhas, P.S., 2002. Post-irrigation impact of domestic sewage effluent on composition of soils, crops and ground water-A case study. Environment International 28, 481-486.

Yadav, R.K., Minhas, P.S., Lal, K., Chaturvedi, R.K., Yadav, G., Verma, T.P., 2015. Accumulation of Metals in Soils, Groundwater and Edible Parts of Crops Grown Under LongTerm Irrigation with Sewage Mixed Industrial Effluents. Bull Environ Contam Toxicol, 1-7.

Yang, P., Yang, M., Mao, R., Byrne, J., 2015. Impact of Long-Term Irrigation with Treated Sewage on Soil Magnetic Susceptibility and Organic Matter Content in North China. Bull Environ Contam Toxicol 95, 102-107.

Yao, H., Zhang, S., Xue, X., Yang, J., Hu, K., Yu, X., 2013. Influence of the sewage irrigation on the agricultural soil properties in Tongliao City, China. Front. Environ. Sci. Eng. 7, 273-280.

Zhang, C., Qiao, Q., Piper, J.D., Huang, B., 2011. Assessment of heavy metal pollution from a Fesmelting plant in urban river sediments using environmental magnetic and geochemical methods. Environmental Pollution 159, 30573070 . 
مياه الصرف الصحي كمصدر بديل للري : التأثير على خواص التربة وحالة الفلزات الثقيلة

\author{
أحمد سعيد أبوزيد \\ قسم الأراضي والمياه - كلية الزراعة - جامعة بنها
}

الملذص العربي

على الرغم من أن الري بمياه الصرف الصحي هو البديل للماء العذب في مصر ، إلا أنه يجب تقييم هذه الممارسة جيداً. تم أخذ عدد 36 عينة

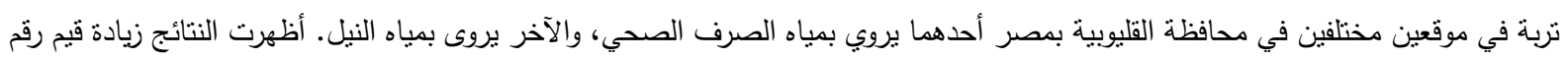

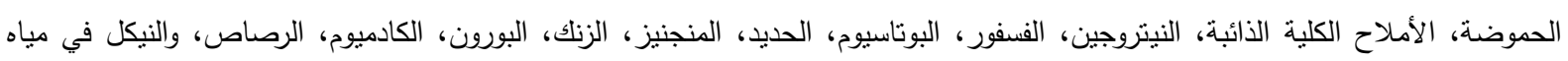

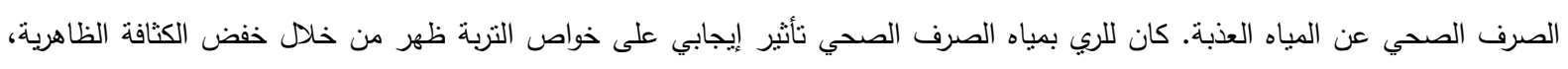

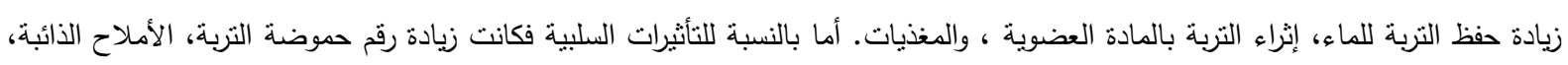

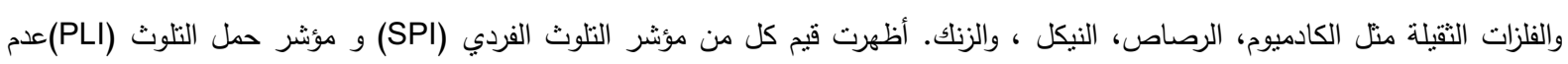

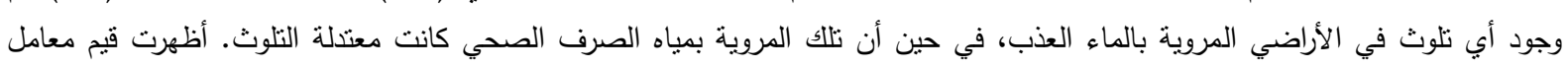

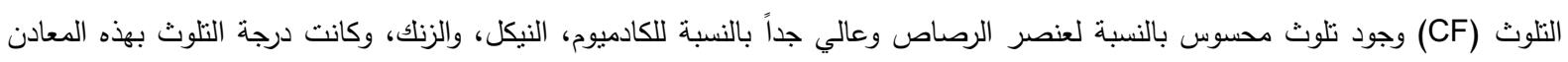

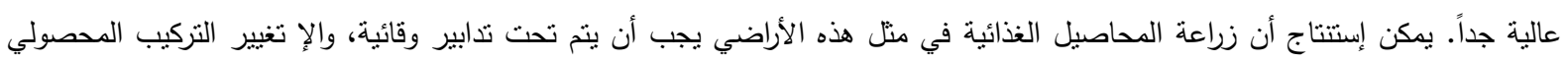

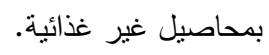

